\title{
Curriculum in an Islamic University
}

\author{
HasinaBanuShirin $^{1^{*}}$, Mohammad Serazul Islam ${ }^{2}$ \\ ${ }^{I}$ Bachelor of Arts (English), Masters of Arts (English), Doctor of Philosophy (Education) \\ ${ }^{2}$ Bachelor of Business Administration, Masters of Management, Doctor of Philosophy (Management) \\ *Corresponding Author: HasinaBanuShirin, Bachelor of Arts (English), Masters of Arts (English), \\ Doctor of Philosophy (Education)
}

\begin{abstract}
An Islamic university is a place from where students get Islamic society's intellectual heritage. Therefore, the Islamic university should have a well-designed curriculum by which students can gain different aspects of Islamic knowledge. In Islamic tradition, seeking knowledge is an integral part of human life. Islam has emphasized on two sorts of knowledge - reveal knowledge which comes directly from Allah (SWT) and earthly knowledge which is discovered by human beings. In this present era higher educational curriculum is designed by the objectives of utilitarianism and pragmatism neglecting the Islamic views. The writers of this analytical study would like to promote a better and brief comprehensive understanding of curriculum in an Islamic university. In this stage for addressing the research questions the definition of Islamic university has been discussed. Secondly, what's the wrong of a conventional university curriculum bears has been be shown. Furthermore, how conventional university'scurriculum is different from the Islamic university'scurriculum has beenanalyzed briefly. Then the writers has discussed all the arguments to suggest about the category of curriculum that should be established in an Islamic university.
\end{abstract}

Keywords: Conventional University, Comprehensive, Islamic university, Islamic views, Pragmatism, Utilitarianism

\section{INTRODUCTION}

A university is an institution which provides both undergraduate and post graduate education. It is a large and diverse institution for dedicating teaching, learning, research and community engagement. Therefore, a well-planned curriculum must be established in an Islamicto disseminate diverse Islamic knowledge and teaching among Muslim students as well as Muslim Ummah.Islam encourages to acquire two types of knowledge which are namely revealed knowledge directly commanded from Allah (swt) and earthly knowledge learned by human beings. AbuSulayman(1989) describes the plan of university for introducing a system whereby graduates in five years obtain two degrees - one is revealed and another one is worldly knowledge.

Nevertheless in order for theadvancementof Islamic university curriculum, appropriate teaching materials and moral excellence achievement are necessary. According to Al-Attas (1989) the aim of a university is to emphasizethe commencement that the dissection betweenFarduAin and FarduKfayyah do not imply that there is no connection between the two; rather this splitting up is a moral one in order to prevent compulsory knowledge being absorbed into worldly knowledge. Once moreAl-Attas (1989) claims that to comprehend what we expect from a university firstly we must have to perceive the nature of mankind similarly in order for us to cognize the nature of mankind we must have to understand the Qur'anic teaching regarding human being, which deals not only with the body but also with the soul.

Nowadays in this universe everyone concede that there has been adetonation of awareness on Islamic study. Hasim (2004) views that Muslim education has been experiencing transformation ever since the period of contact with the West in the eighteenth century in an attempt to face global challenges and position of Muslims in the world community. The objective of an Islamic university curriculum is to grow an individuals' personality, his intellect, feeling, his rational self and so on. The ultimate aim of Muslim education lies in the realization of complete submission to Allah on the level of the individual, the community and humanity at large (Ashraf, 1985). In order to develop our Islamic sense and to Islamize our educational system we must have to establish our university educational 
curriculum base on the Islamic world view. Langgulun (2004) argues that in order for Islamization of curriculum Islamic university is required to place the four components of curriculum namely aim and objectives, content, methods of teaching and methods of evaluation within the Islamic world view.

\section{Problem Statement}

As a Muslim the purpose of our university education should be human development and producing a good man by the Islamic curriculum. Therefore, unfortunately forgetting Islamic curriculum we are giving more priority on the national development and on producing a good citizen by the pragmatic university curriculum. It is well known that the curriculum of an Islamic university is derived from the secular world view. Consequently, the knowledge which is taught in the university is different from the Islamic world view. Hasim (2004) claims, "as a consequence of the Western influence, the university curriculum in Muslim countries are still compartmentalized into the various divisions of natural sciences, social sciences, applied sciences, humanities and religious sciences, without having any fundamental knowledge to bind them together and give them unity".

Students attain knowledge from their educational institutions so universities are the place to disseminate knowledge among students throughout the world. The students who come to an Islamic university can develop their mentality and activity according to Islamic curriculum. The knowledge which we are achieving in recent time is not neutral rather this knowledge also reflects the vision of a particular society. Moreover, for leading society in a specific direction and for being an Islamic the curriculum of an Islamic university should be promoted according to the Islamic worldview. In addition, if we apply Islamic courses and Islamic dress code in a university we cannot claim that the university is Islamic. At the time of preparing curriculum for an Islamic university we have to possess specific vision and mission. Ishaqfarhan (1989) says that spirit, vision and mission make a university Islamic. Furthermore, he argues, "the knowledge must be unified Iman must be reinforced. Students must be given a sense of responsibility. The philosophy and aims of the university, its view of knowledge, education and instruction, students' life and activities of students and evaluation are unique features of an Islamic university".In this article the researchers would like to promote a better and brief comprehensive understanding of curriculum in an Islamic university.

\section{Research questions:}

1. What is an Islamic university?

2. What's wrong with the curriculum of a conventional university?

3. How different is the curriculum of the conventional university from that of the Islamic university?

4. What should be the curriculum in an Islamic university?

In order to analyze the above mentioned research questions first of all the definition of an Islamic university will be illustrated. Secondly, what's the wrong of a conventional university curriculum bears will be discussed. Nevertheless, how conventional university curriculum is different from the Islamic university curriculum will be analyzed briefly. Finally the category of curriculum that must be applied in an Islamic university will be discussed.

\subsection{Definition of an Islamic university}

An Islamic university is a unique educational institution for achieving higher learning. Religious and other educational systems are integrated in an Islamic university. The paramount objective of the university is to symbolize the hopes and aspirations of the Muslim Ummah. Theological instruction and other Islamic studies are provided in an Islamic university. According to Ilyas Ba-Yunus (1989) an Islamic university should reflect the idea of dedication to Allah (swt) and the students should uphold good and prevent evil. Moreover, he argues (1989) that all knowledge should be gathered within the framework of revealed knowledge and there should be community involvement. Many Muslim scholars and practitioners who are saturated with the Islamic ideology are generated from the Islamic university. These scholars and practitioners become expert to teach political, technological, intellectual and other subjects which are essential for the Muslim Ummah.

Ishaqfarhan (1989) states that spirit, vision and mission make a university Islamic and whatever the discipline, the Islamic spirit should permeate the university.His comment is really praiseworthy because an Islamic university has belonged some vision and mission. Emphasizing on the Islamic 
curriculum, the vision of an Islamic university is to develop the higher learning, research instruction and training in different sorts of knowledge. Secondly, it is an excellent dream of an Islamic university to produce a balanced and harmonious human personality by developing and reconstructing the curriculum which is put firmly and deeply into the Islamic worldview and instilled with Islamic idealism.

On the other hand, an Islamic university possesses some missions, too. The main purpose of this university is to establish and define the applicability of Islam into the whole human life, action and thought in this changing modern era. This university has its own framework of the values, ideals, principles and norms of Islam. By this framework an Islamic university intends immensely to provide a profound intellectual and scholastic foundation for various subjects namely economic, moral, ideological, social, intellectual, and technical for the development of Muslim Ummah.

\subsection{What's wrong with the curriculum of a conventional university?}

A conventional university is an educational institution from where people achieve both undergraduate and post graduate degrees in a variety of subjects. This university has different types of faculty such as social sciences, science and technology, psychology and social work, engineering, and information technology and so on. The curriculum of a conventional university is designed:

1. To diffuse knowledge in the social sciences and related fields by means of proper teaching and research.

2. To produce graduates (having sufficient ability) who are ready to serve the nation for peace and prosperity.

3. To establish strong relationship among the various sectors even the national and international levels.

4. To produce well skilled and properly trained professionals in various fields such as counseling, social work, industry and organization and vice versa.

5. To assist people for being more creative and active.

6. To prepare the students with essential knowledge and skills in problem solving and analytical thinking.

7. To dilate knowledge by dint of research.

In Islamic perspective there remains something wrong in the curriculum which is designed for a conventional university; because education is a procedure which implicates the complete person including the spiritual, rational and social dimensions. Sayed Muhammad al-Naquib al-Attas (1989) views that the comprehensive and integrated approach to education in Islam is directed towards the balanced growth of the total personality through training Man's spirit, intellect, rational self, feelings and bodily senses such that faith is infused into the whole of his personality. In conventional educational curriculum faith is not observed which possesses man's spirit, rational self, feelings and bodily senses in Islamic view. This university only wants to produce the active and creative graduates who have proper training to serve the nation for the peace and prosperity. It has no intention to build the graduates as a complete person having spirit, intellect, rational self, feelings and bodily senses which is the fundamental demandof Islamic educational curriculum. The conventional university only provides secular knowledge to the students for solving the problem and analytical thinking.

Therefore, this conventional university never includes Islamic knowledge in the educational curriculum. No endeavor is shown in this university curriculum to comprehend the students with the Islamic legacy and contemporary knowledge. S. ParezManzoor claims (1989)that Muslims must know the legacy and modern knowledge and these are our main aim. Furthermore, he says (1989) "we really need an Islamic vision for the future world order". Regarding the knowledge of Islamic legacy Ziauddinsarder (1989) views that the legacy should be presented as dynamic, living entity, not as history and the legacy must be rediscovered critically. All Muslims shouldseek knowledge on the history and legacy of Islam.

On the other hand, all conventional universities do not belong to the same curriculum theory which we find in Islamic universities whose vision and mission are approximately the same. Conventional 
university designs its educational curriculum as the secular curriculum theory which is set up relying on the overall worldview by the Western education theorists. Different theorists introduced different curriculum theory. For instance four types of curriculum theories namely 1. Essentialism, 2. Encyclopedism, 3. Politechnicalism and 4. Pragmatism have been introduced by Brain Holms and Martin McLean (1989). Contrarily five contradictory curriculum viewpoints have been exposed by Eliot Eisner (200). These viewpoints are namely viewpoint of development and expansion of mental and rational process, viewpoint of academic rationalism, viewpoint of self-dehiscence and selfrelation, viewpoint of social matching reconstruction and viewpoint of curriculum as technology.

Moreover, the secular curriculum theorists' established curriculum theories from different world views relating to their own field of courses. In this way curriculum theory among the conventional universities is in a contradictory position. Hence among the Islamic universities we notice approximately the same curriculum theory. Because all Muslim curriculum planners plan Islamic educational curriculum theory relying on Islamic world-views which does not vary from person to person and which has the same goal and objective.

\subsection{How different is the curriculum of a conventional university from that of an Islamic university?}

Hasim (1998) opines, "Curriculum is so important that it has been named the queen of educational sciences. Curriculum is a reflection of the educational philosophy of the institution concerned, in fact, the mechanism by which its goals are attained". To Islamize our knowledge we need Islamic educational curriculum. Islamic university curriculum is uniquely different from that of conventional university. There is no similarity between these two university curriculums; because all Islamic educational curriculums are surrounded by the influence of the Holy Qur'an. This Holy Qur'an serves as a comprehensive blueprint for both the individual society as the primary source of knowledge. Islamic educational curriculum fosters cooperation for the realization of common objectives in different parts of this world. For advancing the Islamic learning and knowledge Islamic curriculum elevates and encourages mutual understanding among the Islamic educational institutions. In this modern world in the context of the intellectual and spiritual progress Islamic curriculum expounds the teaching of Islam. Emphasizing on Islamic learning (social, political, applied, communication and so on) Islamic curriculum elevates and promotes education, training and research. In contrast, in the fields of consulting, marketing, business, technology, information, education and social sciences conventional university curriculum boosts the courses for preparing the students with the essential skills and knowledge. In order to prepare the students for their careers in different fields' conventional university is observed to work with industries and various agencies collaboratively. The paramount purpose of the conventional university curriculum is to create manpower which is united and trained in specific disciplines. It intends to build the secular thinking, analyzing and evaluation among the students. But it does not bother to establish Islamic thinking among the students. The endeavor of the conventional university curriculum is to create the students' capability to contribute to the country development and at the same time to fulfill all educational demands. Willmott (1990) states, "the freedom so beloved of modern universities has meant that they no longer reflect mankind because they deny the soul and therefore it does not reflect the mankind".

Besides this in order for us to understand the nature of mankind we must haveto understand the Qur'anic teaching regarding human beings which deals not only with the body but also with the soul (Al-Attas, 1989). Conventional curriculum does not nourish Islamic mentality which is essential for every Muslim learner. In this curriculum we notice only worldly knowledge even it also follows the secular educational curriculum theory in which Islamic sense is totally absent.

In Islamic university Islamic disciplines, Islamic thought and civilization, history, fiqhoccupy the central position which is not observed in the curriculum of a conventional university. Islamic curriculum theory is applied in the Islamic university. Depending on the current requirements of the society and Islamic world view Islamic curriculum theorists' designed the Islamic educational curriculum theory. Alamol-Hoda (2005) claims the purpose of Islamic education is to proving presence unification though looking at God's creatures in the surrounding and the nature at large and it wants to transfer the mixture of all presence and acquisition knowledge in an effective way to its students. Again Alamol-Hoda (2002) sates, "the approach of combining curriculum provides for adverse possibilities to expand attitude by looking at the creatures toward proving presence 
unification". The curriculum involves the learners' experiences in various fields of their lives such as emotional, artistic, religious, intellectual, spiritual and moral issues (Shamshiri, 2006). Truly speaking, in all Islamic universities we find approximately the same educational curriculum which is disappeared among all conventional universities. "All education viewpoint which is based on Islamic worldview has advantages as a source for eliciting the native curriculum theory. These advantages include both differences with the common education viewpoints in the West besides having enough capacity for deducing the curriculum theory" (Salsabili, 2008).

\subsection{What should be the curriculum in an Islamic university?}

In Islam, education is twofold and similarly in an Islamic university we perceive these two sorts of education one is from intellectual knowledge and another one is from spiritual knowledge. However if we turn our concentration to the conventional university we will see that there remains only one type of education which is derived from the secular or worldly knowledge. The students of those conventional or modern universities are deprived of achieving the Islamic knowledge which is essential for surviving in this world and the world hereafter. Noor Naemah Abdul Rahman, Asmak Ab Rahman, Abdul Karim Ali (2012) claim that faith is a distinguishing factor lacking in secular oriented universities and again he says that the power of reason has been neglected by most Islamic universities. Neglecting the dichotomous knowledge Ahmed (1988) says that real knowledge is not possible without constructively applying reason to the Qur'an and Sunnah. For every Muslim society Islamic education is required and as a Muslim every individual should be educated by the Islamic educational curriculum. In order to survive in this current universe conventional educational curriculum is important but for being a real Muslim we have to acquire both types of educations. In other words, we should perceive that secular and spiritual knowledge are the two sides of the same sphere.

Moreover in the holy Qur'an the necessity of education is stated repetitively. For example, "O my lord! Increase me in knowledge" (20:14) and in another verse Allah says, "Allah will exalt those of you who believe and those who have knowledge to high degrees" (58:11). In an Islamic university curriculum of all courses should be designed including the Islamization of knowledge which is the demand for the Muslim Ummah. In 1977 the first Islamic educational world conference was held in Makkah. For Islamization of knowledge the Makkah conference has established some specific recommendations. The international Islamic university, Malaysia is the first Islamic university in this globe and it was established after the first Islamic educational world conference. After establishing this university there have been established other Islamic universities in several parts of the world such as Islamic university in Islamabad Pakistan, Uganda in Africa and Kustia in Bangladesh. In an Islamic university the curriculum is designed according to the Islamic perspective to fulfill the demand of the Muslim Ummah. Shah Abdul Hannan (2010) says, "Islamization of education is significant because the root cause of all problems and malaises of the Ummah, the Muslim community is education".

In addition if we observe our past Islamic history we will be informed that during the Abbasi, Usmania or Mughul period the educational curriculum was produced by the twofold of knowledge which were conventional and Islamic. Because the civil servants even the army generals were educated by the coaching of modern education and that of the Qur'an and Sunnah, the tradition of the Prophet (saw), fiqh, Islamic law and jurisprudence. So like our ancient golden age we have to establish our university educational curriculum in the Islamic worldview along with the concept of the modern worldview.

\section{CONCLUSION}

In this essay, the researchers have tried to flourish the Islamic university educational curriculum and for this reason the various sides of educational curriculum are discussed. On the other hand, to establish the actual Islamic university educational curriculum the researchers have shown the curriculum differences between the conventional university and that of the Islamic university. They have attempted to expose the aims and objectives, vision and mission which is closely related with the educational curriculum design and formation. Basically, the Islamic educational curriculum is designed for making a good man not only for making a good citizen. Another objective of this curriculum is to give the meaning of human lives and enrich these lives with the light of the Islamic perspective and values which is mentioned in the holy Qur'an "As Allah has taught him, so let him 
write" (2:282). Moreover for supporting their arguments the researchers have reviewed certain related scholarly literatures. At last they attempted to generate their arguments in favor of an Islamic university educational curriculum by mentioning the past historical Islamic educational curriculum.

\section{REFERENCES}

[1] Ahmed, A. S. (1988). Islam: Making Sense of Muslim History and Society. London: Routledge.

[2] Abu Sulayman, A. H. (1989). Islamization of Knowledge. Riyadh: International Islamic Publishing House and IIIT.

[3] Abu Sulayman, A. H. (ed.) (1989). Islamization of Knowledge: General Principles and Workplan. Herndon, VA: IIIT.

[4] Al-Attas, Syed Muhammad Naquib (1989). Islam and the philosophy of science, International Institute of Islamic Thought and Civilization (ISTAC), Kuala Lumpur, Malaysia.

[5] Alamol-Hoda (2005). Foundations of Islamic education and curriculum planning (on the basis of Sadra's philosophy). Tehran: Imam Sadegh University publications.

[6] Ashraf, Syed Ali. (1985). New Horizons in Muslim Education. Cambridge: Hodder and Stoughton.

[7] Ba-Yunus, Ilyas. (1988). Al-Faruqi and Beyond: Future Directions in Islamization. American Journal of Islamic Social Sciences, 5(1), 13-28.

[8] Eisner. E. W. (2004). Multiple Intelligences: Its Tensions and Possibilities. Teachers College Record, 106(1), 31-39.

[9] Hashim, R. (2004). Educational Dualism in Malaysia Implications for Theory and Practice (2nd edition). Oxford University Press, New York.

[10] Hashim, R. (2004). Educational dualism in Malaysia: Implications for theory and practice (2nd ed.). Kuala Lumpur: The Other Press.

[11] Holms, B. \& McLean, M. (1989). The Curriculum: A Comparative Perspective. London: Routledge.

[12] IshaqFarhan (1989). Islamization of the Discipline of Education. The American Journal of Islamic Social Sciences, 6(2), 307-318.

[13] Langgulung, H. (2004). Education, Islam and Muslim in the 21st Century: Image and reality. Paper presented at: International Conference on Muslim Education in the 21st Century PWTC, Kuala Lumpur (46August).

[14] Noor Naemah Abdul Rahman, Asmak Ab Rahman, Abdul Karim Ali (2012). A Study on Students' Research Related to Fatwa Submitted at Malaysian Public Universities. International Journal of Humanities and Social Science, 2(18), 129-138.

[15] Salsabili, N. (2008). The movement of Iran's curriculum planning system towards decentralization of curriculum design with an emphasis on school-based curriculum. Curriculum Studies Quarterly, 1(4).

[16] Shamshiri, B. (2006). Education from the perspective of love and mysticism. Tehran: Tahouri Publications.

[17] Shah Abdul Hannan (2010). The Islamic Education Movement: A Recent History and Objectives. Retrived from http://ehlt.flinders.edu.au/education/iej/articles/v7n4/Faruqi/paper.pdf

[18] S. ParezManzoor (1989). Desacralizing Secularism. The American Journal of Islamic social Sciences, 12(4), 545-559.

[19] Willmott, H. (1990). Serving the public interest? A critical analysis of a professional claim. In: D.Cooper and T.Hoppereds, Critical accounts. London: Macmillan.

[20] Ziauddinsarder (1988). Islamic Futures: The Shape of Ideas to Come. Kuala Lumpur: Pelanduk Publication.

Citation: HasinaBanuShirin, Mohammad Serazul Islam. Curriculum in an Islamic University. International Journal of Managerial Studies and Research. Volume 6, Issue 1, January 2018, PP 15-20. http://dx.doi.org/10.20431/2349-0349.0601003

Copyright: ( 2018 Authors. This is an open-access article distributed under the terms of the Creative Commons Attribution License, which permits unrestricted use, distribution, and reproduction in any medium, provided the original author and source are credited. 